\title{
A hemicryptophane with a triple-stranded helical structure
}

\author{
Augustin Long ${ }^{1}$, Olivier Perraud ${ }^{2}$, Erwann Jeanneau ${ }^{3}$, Christophe Aronica $^{3}$, \\ Jean-Pierre Dutasta ${ }^{2}$ and Alexandre Martinez ${ }^{* 1}$
}

\author{
Full Research Paper \\ Address: \\ ${ }^{1}$ Aix Marseille Univ, CNRS, Centrale Marseille, iSm2, Marseille \\ France, ${ }^{2}$ Laboratoire de Chimie École Normale Supérieure de Lyon, \\ CNRS, UCBL46, Allée d'Italie, F-69364 Lyon, France and ${ }^{3}$ LMI-UMR \\ 5615 CNRS / UCBL, Université Claude Bernard Lyon 1, 6 rue victor \\ Grignard, 69622 Villeurbanne cedex, France \\ Email: \\ Alexandre Martinez ${ }^{*}$ - alexandre.martinez@centrale-marseille.fr \\ * Corresponding author \\ Keywords: \\ CTV; hemicryptophanes; organic cages; triple helical structure
}

Beilstein J. Org. Chem. 2018, 14, 1885-1889. doi:10.3762/bjoc. 14.162

Received: 15 April 2018

Accepted: 29 June 2018

Published: 24 July 2018

This article is part of the thematic issue "Macrocyclic and supramolecular chemistry".

Guest Editor: M.-X. Wang

(c) 2018 Long et al.; licensee Beilstein-Institut. License and terms: see end of document.

\begin{abstract}
A hemicryptophane cage bearing amine and amide functions in its three linkers was synthesized in five steps. The X-ray molecular structure of the cage shows a triple-stranded helical arrangement of the linkers stabilized by intramolecular hydrogen bonds between amide and amine groups. The chirality of the cyclotriveratrylene unit controls the propeller arrangement of the three aromatic rings in the opposite part of the cage. ${ }^{1} \mathrm{H}$ NMR studies suggest that this structure is retained in solution.
\end{abstract}

\section{Introduction}

Among the remarkable architectures found in biological systems, those presenting a triple helical arrangement are of particular interest. Beside its classical double strand structure formed by Watson-Crick base pairing, DNA can also organize in a triple helical fashion [1]. These three-stranded structures of DNA naturally occur and play important roles in regulating gene function and DNA metabolism. Collagen, the most abundant protein in animals, also adopts a triple helical structure: three parallel peptide chains coil about each other in a triple stranded left-handed helical structure. Its high thermal and mechanical stability results mainly from the numerous hydrogen bonds found in the triple helix framework [2]. Bioinspired structures, based on peptide backbones, have been built, allowing a better understanding of the properties of this biological system and giving rise to numerous applications ranging from artificial collagenous biomaterials to peptides for therapeutic uses [3-5].

Recently, molecular cages presenting a triple helical structure have aroused a considerable interest [6-8]: for instance, Malik et al. described the synthesis and recognition properties of an organic cage including three helicene moieties in its arms [9]. This cage presents a triple stranded helical structure with the framework fully twisted due to the arrangement of the three helicene units in a propeller fashion. Other recent examples are the triple-stranded phenylene cages presenting a helical rod-like shape synthesized by Kirsche et al. [10].

Hemicryptophanes are chiral covalent cages combining a cyclotriveratrylene (CTV, north part) unit with another $C_{3}$ sym- 
metrical moiety (south part). They display recognition properties toward neurotransmitters and carbohydrates, and can act as molecular switches and supramolecular catalysts [11]. Their $C_{3}$ symmetry makes them promising candidates to build molecular cages displaying a triple helical arrangement of the linkers. Furthermore, we have previously reported that the chirality unit in the south part and the chirality of the CTV unit in the north part influence each other, suggesting that the chirality of the CTV moiety could control the helical arrangement of the linkers $[12,13]$.

We herein report the synthesis of the hemicryptophane 1 bearing both amide and amine functions in its three likers. In solution, the ${ }^{1} \mathrm{H}$ NMR spectrum shows a $C_{3}$ symmetrical cage, which is also observed in the solid state by X-ray crystallography. Moreover, in the solid, amide and amine functional groups of different linkers interact through hydrogen bonding, leading to a triple helical arrangement of the linkers. The CTV unit is also found to strongly control the chirality of this triple helices since the CTV with a $P$ (respectively $M$ ) configuration induces a $\Delta$ (respectively $\Lambda$ ) chirality of the propeller-like arrangement of the linkers.

\section{Results and Discussion Synthesis of cage 1}

According to the synthetic pathway shown in Scheme 1, hemicryptophane host $\mathbf{1}$ was obtained in five steps [14,15]. Alkylation of vanillyl alcohol by chloroacetic acid in ethanol under reflux afforded $\mathbf{2}$ in $73 \%$ yield. The CTV triester was obtained by adding first one equivalent of $\mathrm{HCl}$ and then a catalytic amount of para-toluenesulfonic acid in methanol to compound $\mathbf{2}$. Then, compound $\mathbf{3}$ was reacted with ethylenediamine, providing 4 in $48 \%$ yield. The reaction between 1,3,5tris(bromomethyl)benzene and 2-hydroxybenzaldehyde provi-<smiles>COc1cc(CO)ccc1O</smiles><smiles>COc1cc(CO)ccc1OCC(=O)O[Na]</smiles>

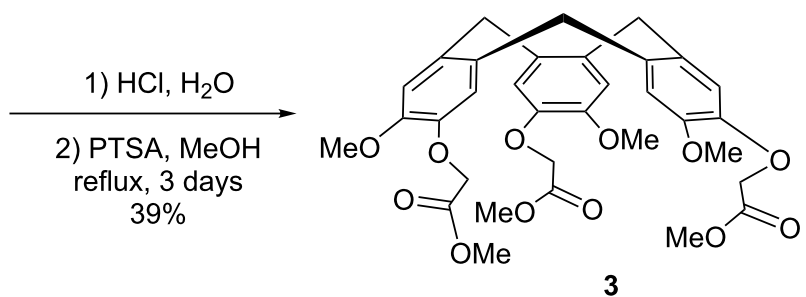

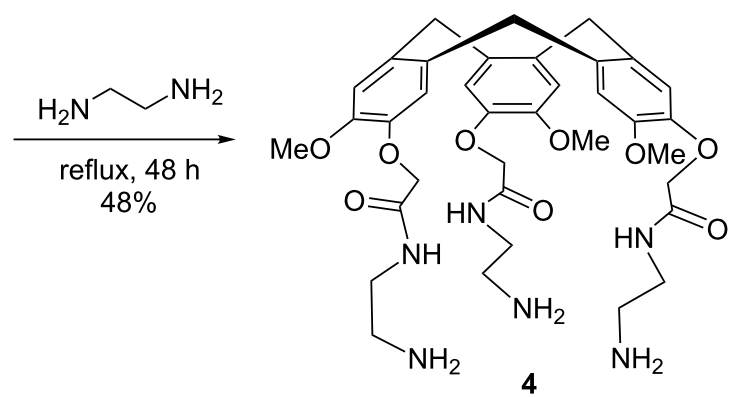<smiles>O=Cc1ccccc1O</smiles><smiles>O=Cc1ccccc1OCc1cc(COc2ccccc2C=O)cc(COc2ccccc2C=O)c1</smiles>

1) 4 , $\mathrm{CHCl}_{3} / \mathrm{MeOH}$

$(1: 1)$ $\mathrm{rt}, 18 \mathrm{~h}$

2) $\mathrm{NaBH}_{4}$ $0{ }^{\circ} \mathrm{C}$ to $\mathrm{rt}, 3 \mathrm{~h}$ $92 \%$

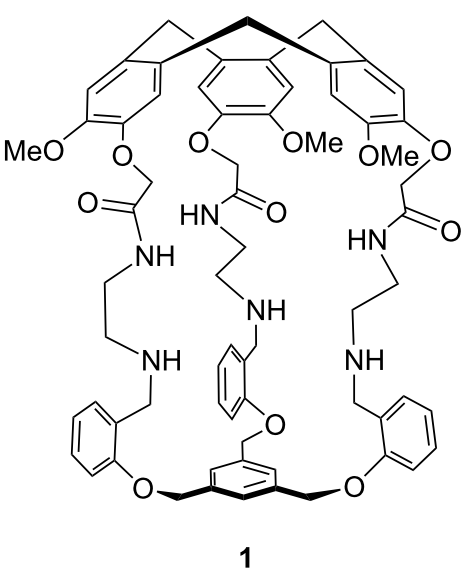


ded the precursor of the south unit $\mathbf{5}$ in 78\% yield. Finally, a $[1+1]$ macrocyclization between $\mathbf{4}$ and $\mathbf{5}$ was achieved by a reductive amination in a $1: 1 \mathrm{CHCl}_{3} / \mathrm{MeOH}$ mixture. A remarkable yield of $92 \%$ was obtained for this last step. As this kind of reductive amination has been proved to be under thermodynamic control, the resulting intermediate cage bearing three imine functions is highly sable $[12,13]$. Hydrogen bonds between the amide group and the formed imine function could account for the high stability of this intermediate, shifting the equilibrium between the different oligomers and the cage in favor of this latter (vide infra).

\section{${ }^{1} \mathrm{H}$ NMR of cage 1}

The ${ }^{1} \mathrm{H}$ NMR spectrum of hemicryptophane $\mathbf{1}$ in $\mathrm{CDCl}_{3}$ shows that this host presents, on average, a $C_{3}$ symmetry in solution (Figure 1). The characteristic signals of the CTV unit can be observed: one signal for the OMe group at $3.94 \mathrm{ppm}$, two singlets for the aromatic protons at 6.58 and $6.75 \mathrm{ppm}$ and the expected $\mathrm{AB}$ systems for the $\mathrm{CH}_{2}$ bridges at 4.67 and $3.44 \mathrm{ppm}$. The aromatic protons of the benzene ring in the south part of the cage and the corresponding diastereotopic $\mathrm{CH}_{2}$ bridges displays a singlet at $7.46 \mathrm{ppm}$ and two doublets at 5.11 and $4.92 \mathrm{ppm}$, re- spectively. The signals of the aromatic protons of the linkers give two doublets and two triplets between 6.75 and $7.2 \mathrm{ppm}$, whereas the diastereotopic aliphatic protons exhibit expected broad multiplets between $1.50 \mathrm{ppm}$ and $2.36 \mathrm{ppm}$. The $\mathrm{Ar}-\mathrm{CH}_{2}-\mathrm{NH}$ diastereotopic protons appear as two doublets at 3.87 and $3.49 \mathrm{ppm}$.

\section{Structure of cage 1}

Slow evaporation of a solution of cage 1 in a 1:1 mixture of $\mathrm{CHCl}_{3} / \mathrm{MeOH}$ affords crystals suitable for X-ray diffraction. In the solid, the hemicryptophane cage presents a perfect $C_{3}$ symmetry (Figure 2). Further examination of the crystal structure reveals that $\mathbf{1}$ adopts a chiral conformation where the three linkers are twisted into a triple helix with the lone pair of the amines and the amide hydrogen atoms oriented toward the cavity, while the amide oxygen atoms are oriented outwards. Intramolecular hydrogen bonding between the nitrogen of the amine function of one linker with the $\mathrm{N}-\mathrm{H}$ of the amide group of another arm can account for this helical structure $\left(\mathrm{N}_{\text {amine }} \cdots \mathrm{N}_{\text {amide }}\right.$ distances of $2.97 \AA$ ). This structure sheds light on the excellent yield achieved in the last step of the synthesis. Indeed, such intramolecular hydrogen bonding probably also

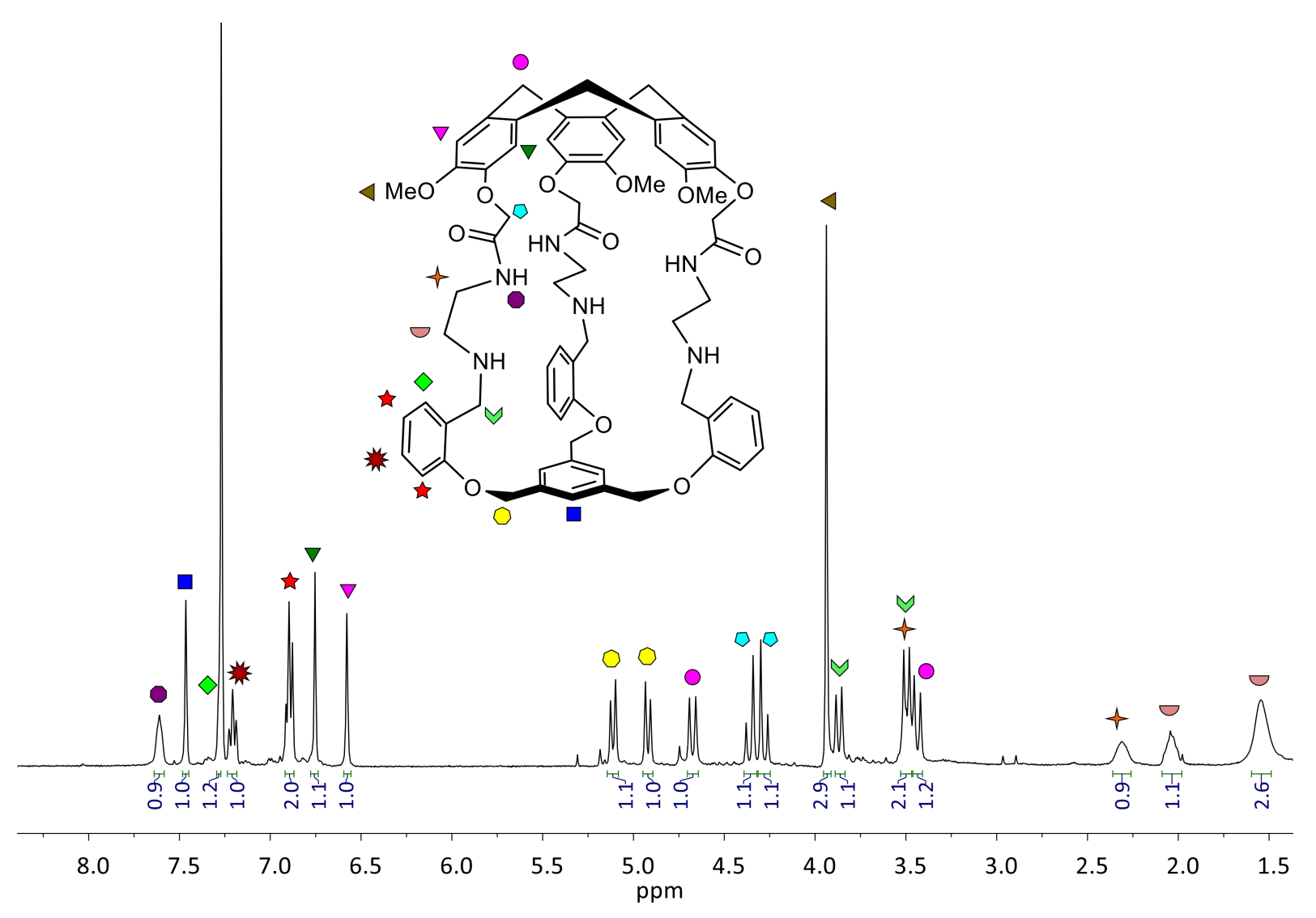

Figure 1: ${ }^{1} \mathrm{H}$ NMR spectrum of $1\left(400 \mathrm{MHz}, \mathrm{CDCl}_{3}\right)$. 

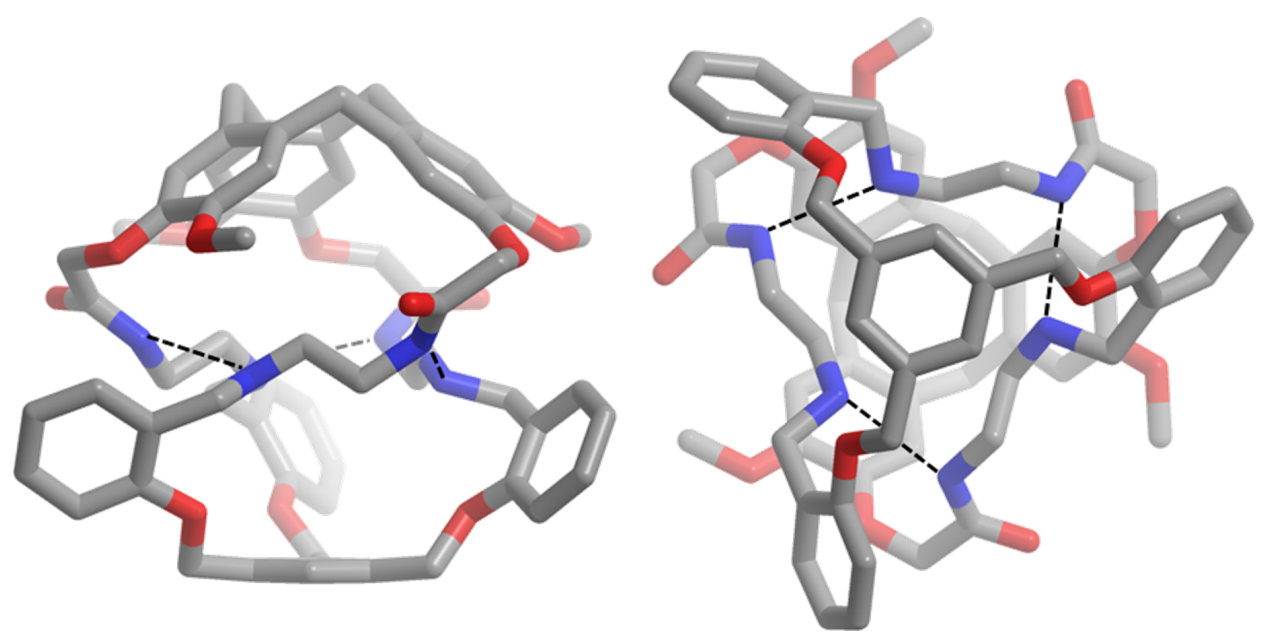

Figure 2: X-ray molecular structure of 1. Hydrogen atoms are omitted for clarity; dashed lines represent hydrogen bonds.

occurred in the imine precursor, accounting for its high thermodynamic stability compared to oligomers that could also be formed during the reaction between $\mathbf{4}$ and $\mathbf{5}$.

Interestingly, one can also see that the CTV with the $P$ configuration (respectively $M$ ) imposes a $\Delta$ (respectively $\Lambda$ ) propellerlike arrangement of the lateral arms, with a $120^{\circ}$ turn around the $C_{3}$ axis of the molecule (Figure 2). This also underlines how the chirality of the CTV unit propagates along the linkers to induce the propeller shape of the three aromatic rings in the south part of the hemicryptophane. This remote control of the helicity of the southern part by that of the northern CTV unit, through nine bonds, is allowed by this specific triple stranded helical structure, which induces a strong twist of the whole framework.

This helical arrangement probably also occurred in solution. Indeed, the south part of cage $\mathbf{1}$ is similar to that of cage $\mathbf{6}$ (Figure 3) and the comparison between the signals of the (a)

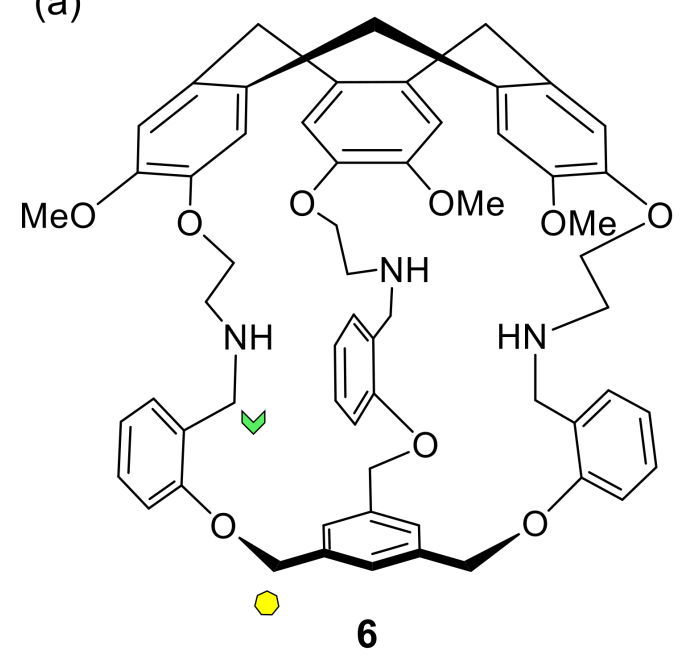

(b)

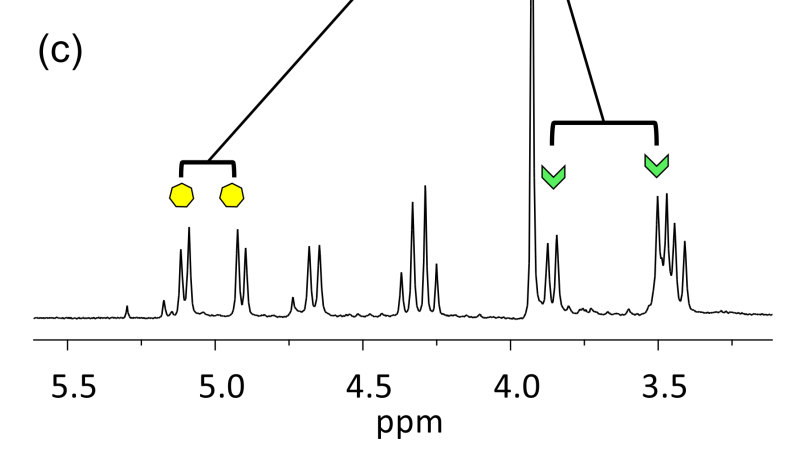

Figure 3: (a) Structure of compound 6. (b) ${ }^{1} \mathrm{H} N M R$ of $6\left(\mathrm{CDCl}_{3}, 400 \mathrm{MHz}\right)$. (c) ${ }^{1} \mathrm{H} \mathrm{NMR}$ of $1\left(\mathrm{CDCl}_{3}, 400 \mathrm{MHz}\right)$. 
$\mathrm{CH}_{2}-\mathrm{NH}$ and $\mathrm{Ar}-\mathrm{O}-\mathrm{CH}_{2}-\mathrm{Ar}$ protons of cage 6 with those of cage 1 shows respectively downfield and highfield shifts of around $-0.2 \mathrm{ppm}$ and more than $+0.8 \mathrm{ppm}$, respectively [16]. Moreover, the chemical shift differences of the two diastereotopic protons of the two $\mathrm{AB}$ systems are much greater for $\mathbf{1}$ than for 6 with $\Delta \delta=0.38 \mathrm{ppm}$ for the $\mathrm{CH}_{2} \mathrm{NH}$ and of $\Delta \delta=0.19 \mathrm{ppm}$ for the Ar-O- $\mathrm{CH}_{2}-\mathrm{Ar}$ of 1 , compared to $0.07 \mathrm{ppm}$ and $0.05 \mathrm{ppm}$ for $\mathbf{6}$, respectively (Figure 3 ). This is consistent with a more rigid structure of cage $\mathbf{1}$ in solution, as suggested by the solid-state structure.

\section{Conclusion}

In summary, we have described the synthesis of a new hemicryptophane organic cage, which adopts a triple helical structure because of the propeller-like arrangement of its three linkers. The chirality of the CTV was shown to control that of the whole helical cage structure, since only $P-\Delta$ and $M-\Lambda$ enantiomers were observed in solid state. NMR studies suggest that this propeller-like arrangement also occurs in solution. Further investigations are in progress in order to propagate the chirality of the CTV to even more remote opposite sites through the formation of such triple helical structures.

\section{Supporting Information}

\section{Supporting Information File 1}

Procedures for the synthesis of compounds 1-5; ${ }^{1} \mathrm{H},{ }^{13} \mathrm{C} \mathrm{NMR}$, spectra mass spectra of compound $\mathbf{1}$ and crystallographic data.

[https://www.beilstein-journals.org/bjoc/content/ supplementary/1860-5397-14-162-S1.pdf]

\section{ORCID ${ }^{\circledR}$ iDs}

Christophe Aronica - https://orcid.org/0000-0001-7098-7355 Jean-Pierre Dutasta - https://orcid.org/0000-0003-0948-6097

\section{References}

1. Jain, A.; Wang, G.; Vasquez, K. M. Biochimie 2008, 90, 1117-1130. doi:10.1016/j.biochi.2008.02.011

2. Shoulders, M. D.; Raines, R. T. Annu. Rev. Biochem. 2009, 78, 929-958. doi:10.1146/annurev.biochem.77.032207.120833

3. Hamley, I. W. Chem. Rev. 2017, 117, 14015-14041. doi:10.1021/acs.chemrev.7b00522

4. Pekkanen, A. M.; Mondschein, R. J.; Williams, C. B.; Long, T. E. Biomacromolecules 2017, 18, 2669-2687. doi:10.1021/acs.biomac.7b00671

5. Montero de Espinosa, L.; Meesorn, W.; Moatsou, D.; Weder, C. Chem. Rev. 2017, 117, 12851-12892. doi:10.1021/acs.chemrev.7b00168

6. Míguez-Lago, S.; Llamas-Saiz, A. L.; Cid, M. M.; Alonso-Gómez, J. L. Chem. - Eur. J. 2015, 21, 18085-18088. doi:10.1002/chem.201503994
7. Yamakado, R.; Mikami, K.; Takagi, K.; Azumaya, I.; Sugimoto, S.; Matsuoka, S.-i.; Suzuki, M.; Katagiri, K.; Uchiyama, M.; Muranaka, A. Chem. - Eur. J. 2013, 19, 11853-11857. doi:10.1002/chem.201301198

8. Ikeda, A.; Udzu, H.; Zhong, Z.; Shinkai, S.; Sakamoto, S.; Yamaguchi, K. J. Am. Chem. Soc. 2001, 123, 3872-3877. doi:10.1021/ja003269r

9. Malik, A. U.; Gan, F.; Shen, C.; Yu, N.; Wang, R.; Crassous, J.; Shu, M.; Qiu, H. J. Am. Chem. Soc. 2018, 140, 2769-2772. doi:10.1021/jacs.7b13512

10. Sato, H.; Bender, J. A.; Roberts, S. T.; Krische, M. J. J. Am. Chem. Soc. 2018, 140, 2455-2459. doi:10.1021/jacs.8b00131

11. Zhang, D.; Martinez, A.; Dutasta, J.-P. Chem. Rev. 2017, 117, 4900-4942. doi:10.1021/acs.chemrev.6b00847

12. Chatelet, B.; Joucla, L.; Padula, D.; Di Bari, L.; Pilet, G.; Robert, V.; Dufaud, V.; Dutasta, J.-P.; Martinez, A. Org. Lett. 2015, 17, 500-503. doi:10.1021/ol5035194

13. Gosse, I.; Robeyns, K.; Bougault, C.; Martinez, A.; Tinant, B.; Dutasta, J.-P. Inorg. Chem. 2016, 55, 1011-1013. doi:10.1021/acs.inorgchem.5b02750

14. Vériot, G.; Dutasta, J.-P.; Matouzenko, G.; Collet, A. Tetrahedron 1995, 51, 389-400. doi:10.1016/0040-4020(94)00904-9

15. Perraud, O.; Robert, V.; Gornitzka, H.; Martinez, A.; Dutasta, J.-P. Angew. Chem., Int. Ed. 2012, 51, 504-508. doi:10.1002/anie.201106934

16. Long, A.; Perraud, O.; Albalat, M.; Robert, V.; Dutasta, J.-P.; Martinez, A. J. Org. Chem. 2018, 83, 6301-6306. doi:10.1021/acs.joc.8b00276

\section{License and Terms}

This is an Open Access article under the terms of the Creative Commons Attribution License (http://creativecommons.org/licenses/by/4.0). Please note that the reuse, redistribution and reproduction in particular requires that the authors and source are credited.

The license is subject to the Beilstein Journal of Organic Chemistry terms and conditions: (https://www.beilstein-journals.org/bjoc)

The definitive version of this article is the electronic one which can be found at:

$\underline{\text { doi: } 10.3762 / \text { bjoc. } 14.162}$ 